\title{
ANTIFUNGAL EFFECTIVENESS OF CACAO BEAN SHELLS EXTRACT (Theobroma cocoa L.) ON TRICHOPHYTON RUBRUM GROWTH IN VITRO
}

\section{EFEKTIFITAS ANTIFUNGAL EKSTRAK CANGKANG BIJI KAKAO (Theobroma cocoa L.) TERHADAP PERTUMBUHAN TRICHOPHYTON RUBRUM SECARA IN VITRO}

\author{
Chintya Mei Desia Hutasoit ${ }^{1}$, Yuni Setyaningsih ${ }^{2}$, Andri Pramono ${ }^{3}$ \\ ${ }^{1}$ Faculty of Medicine, Universitas Pembangunan Nasional Veteran Jakarta \\ ${ }^{2}$ Departement of Parasitology, Universitas Pembangunan Nasional Veteran Jakarta \\ ${ }^{3}$ Departement of Microbiology, Universitas Pembangunan Nasional Veteran Jakarta \\ Correspondence: dr Yuni Setyaningsih, M.Biomed, Email: yunisetyaningsih@upnvj.ac.id
}

\begin{abstract}
Trichophyton rubrum is the most common dermatophytosis etiology. The antifungal agent has several problems such as fungal resistance and therapy side effects. Cacao (Theobroma cocoa L.) bean shells extract contained flavonoids, alkaloids, and saponins which have an antifungal effect. This study aimed to test the in vitro cacao bean shells extract antifungal (especially: Trichophyton rubrum) effectiveness by agar well diffusion method. This was an experimental study with a post-test only control group design. This study used cacao bean shells extract concentration 25\%, 50\%, 75\%, and 100\%, ketokonazol as positive control, and aquadest as negative control. The average inhibition diameter of 25\%,50\%, 75\% and 100\% cacao bean shells extract concentration were $10.65 \mathrm{~mm}, 18 \mathrm{~mm}, 26.92 \mathrm{~mm}$, and $37.22 \mathrm{~mm}$, respectively, while the ketoconazole inhibition diameter was $51.52 \mathrm{~mm}$. Data were analyzed using the Kruskal-Wallis test and post hoc with Mann-Whitney. The results showed significant differences between each treatment group $(p<0.05)$. Cacao bean shells extract had an antifungal effect in inhibiting the growth of Tricophyton rubrum invitro.
\end{abstract}

Keywords: Trichophyton rubrum, Cacao Bean Shells, Antifungal, Agar Well Diffusion Method,

\section{ABSTRAK}

Trichophyton rubrum adalah penyebab paling umum dermatofitosis. Obat dermatofitosis (antijamur) memiliki beberapa masalah seperti resistensi dan efek samping terapi. Ekstrak cangkang biji kakao (Theobroma cocoa L.) mengandung flavonoid, alkaloid, dan saponin yang memiliki efek antijamur. Tujuan penelitian ini untuk menguji efektivitas antijamur (khususnya Trichophyton rubrum) ekstrak cangkang biji kakao secara in vitro dengan metode difusi agar. Penelitian ini merupakan penelitian eksperimental dengan post-test only control group design. Penelitian ini menggunakan konsentrasi ekstrak cankang biji kakao 25\%, 50\%, 75\%, dan $100 \%$, ketokonazol sebagai kontrol positif, dan aquadest sebagai kontrol negatif. Rata-rata diameter hambat konsentrasi 25\%, 50\%, 75\% dan 100\% secara berturut-turut yaitu: 10,65 mm, 18 mm, 26,92 mm, dan 37,22 mm, sedangkan daya hambat ketoconazole adalah 51,52 mm. Data dianalisis menggunakan uji Kruskal-Wallis dan post hoc dengan Mann-Whitney. Hasil penelitian menunjukkan perbedaan yang signifikan antara masingmasing kelompok perlakuan $(p<0,05)$. Ekstrak cangkang biji kakao memiliki efek antijamur dalam menghambat pertumbuhan Tricophyton rubrum invitro.

Kata kunci: Trichophyton rubrum, Anti-jamur, Cangkang Biji Kaka, Metode Difusi Sumuran Agar

How To Cite: Hutasoit, C., Setyaningsih, Y., \& Pramono, A. (2020). ANTIFUNGAL EFFECTIVENESS OF CACAO BEAN SHELLS EXTRACT (Theobroma cocoa L.) ON TRICHOPHYTON RUBRUM GROWTH IN VITRO. Biomedika, 12(2), 65-71. doi:https://doi.org/10.23917/biomedika.v12i2.10176

DOI: https://doi.org/10.23917/ biomedika.v12i2.10176 


\section{INTRODUCTION}

Dermatophyte infect $10-15 \%$ human population at least once in their lives (Pires et al., 2014). 2010 Indonesia's health profile data showed that skin and subcutaneous tissue diseases are third ranked of ten most diseases in outpatients in hospitals throughout Indonesia based on the number of visit (Kemenkes, 2011). Dermatophytosis is a fungal infection in keratinized tissue (Pereira et al., 2015). Trichophyton rubrum is the most frequently dermatophytosis found in clinical cases. It could be isolated from various superficial and deeper sites of infection, also systemic dissemination in immunocompromised patients (Pereira et al., 2013). Antifungal agents such as griseofulvin, azole derivatives, and allylamine which are used as therapeutic options have some problems in the treatment of dermatophytosis such as fungal resistance, long duration of treatment and therapeutic side effects. In that situation, additional antifungal therapy are needed (Pereira et al., 2015). the process of producing dry cocoa beans produces waste called cacao rind and pulp, then the processing dried cacao bean into cacao products produces waste called cacao bean shells (Kayaputri et al., 2014). Indonesian cacao fruit production was 686,946 tons in 2018
(Direktorat Jendral Perkebunan (Ditjenbun), 2017 ), and $3.6 \%$ of this cacao fruit was cacao bean shells (Kim, et al., 2014), therefore 24,730 tons cacao bean shells be produced.

The cacao bean waste has a low economic value and so far its been used as animal feed and compost only. Phytochemical study on the extract of cacao bean shells (Theobroma cocoa L.) showed antimicrobial compound alkaloid, flavonoid, and saponin which has antifungal effects. Gas Chromatography-Mass Spectrometry of cacao bean shells extract study showed that cacao bean shell contain $89.5 \%$ alkaloid, in the form of caffeine and theobromine (Kayaputri et al., 2014). Flavonoids modulate the pathway of fatty acid synthesis, thereby disrupting the formation of fungal cell walls.

The saponin induces $\mathrm{H}_{2} \mathrm{O}_{2}$, causes fungal lipid membranes peroxidation and makes the membrane permeability increased, so occur the cell leakage (Jiang et al., 2016). Cacao rind had phytochemical content which is not much different from cacao bean shells. A study on cacao rind extract showed that it had antifungal effectiveness against Fusarium oxysporum and acts as a fungicide (Pallawagau et al., 2019). 
There were no research on antifungal activity of cacao bean shells extract, so we interested in this research.

\section{METHOD}

This research was an experimental study (true experiment) using a post-test-only control group research design by agar well diffusion methods. The four groups were treated with cacao bean shells extract with different concentration (there are: $25 \%, 50 \%, 75 \%$, and $100 \%$ ) and the two groups were used as positive (ketoconazole) dan negative (aquadest) control. The study was conducted at the Laboratory of Parasitology at the Faculty of Medicine of Universitas Pembangunan Nasional Veteran Jakarta. Cacao bean shells extract was obtained from BALITRO (an Indonesian Spice and Medicinal Research Institute), the manufacturing process using multilevel maceration techniques with $96 \%$ ethanol solvent.

The number of samples used per group was four Sabouround Dextrose Agar (SDA) preparations containing Trichophyton rubrum. Petri dish was poured by SDA and let it freeze. The well was made by putting a cylindrical plate in the center of the SDA Petri dish.
Trichophyton rubrum then poured over the base layer of SDA. After it was freeze, the cylindrical plate was lifted. The wells then filled with cacao bean shells extract with a concentration of $25 \%$, $50 \%, 75 \%, 100 \%$, positive control and negative control dish at each petri dish. The petri dish was incubated for 48 hours at room temperature. Clear areas indicate the fungal inhibition growth after 48 hours.

Data be analyzed with the Kruskal Wallis test and post hoc Mann Whitney (Dahlan and Dewi, 2009)

\section{RESULT AND DISCUSSION}

The clear area was formed around the well that indicated the Trichophyton rubrum growth inhibition area. This clear area was measured using a digital caliper (table 1).

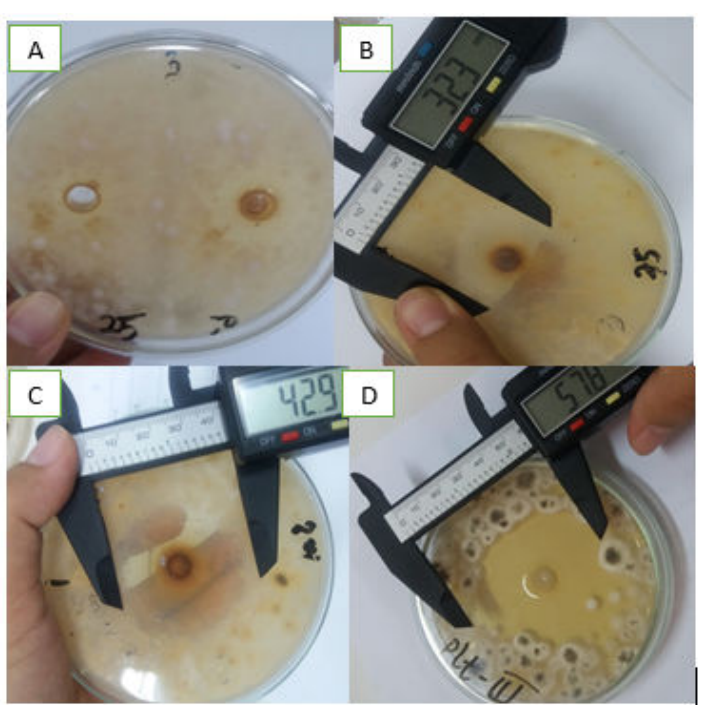

Figure 1. Inhibiton growth on Trichophyton rubrum in different concentration of Cacao bean shells extract. A. $25 \%$ and $50 \%$, B. $75 \%$, C. $100 \%$, D. Ketokoazole 2\% 
Table 1. Growth inhibition of Trichophyton rubrum

\begin{tabular}{|c|c|c|c|c|c|c|}
\hline \multirow[t]{2}{*}{ No. } & \multicolumn{4}{|c|}{$\begin{array}{l}\text { Concentration of cacao bean } \\
\text { shells extract }(\mathrm{mm})\end{array}$} & \multicolumn{2}{|c|}{$\begin{array}{l}\text { Control } \\
(\mathbf{m m})\end{array}$} \\
\hline & $25 \%$ & $50 \%$ & $75 \%$ & $100 \%$ & - & + \\
\hline 1 & 11,7 & 17,5 & 26,5 & 36,9 & 0 & 51,3 \\
\hline 2 & 10,3 & 18,1 & 27,8 & 38,0 & 0 & 50,4 \\
\hline 3 & 10,6 & 18,8 & 26,3 & 36,3 & 0 & 51,8 \\
\hline 4 & 10,0 & 17,6 & 27,1 & 37,7 & 0 & 52,6 \\
\hline $\begin{array}{l}\text { Mean } \\
\pm \mathrm{SD}\end{array}$ & $\begin{array}{c}10,65 \\
\pm \\
0,75\end{array}$ & $\begin{array}{l}18 \pm \\
0,59\end{array}$ & $\begin{array}{c}26,92 \\
\pm \\
0,67\end{array}$ & $\begin{array}{c}37,22 \\
\pm \\
0,92\end{array}$ & 0 & $\begin{array}{c}51,52 \\
\pm \\
0,12\end{array}$ \\
\hline
\end{tabular}

Cacao bean shells extract group with $25 \%$, $50 \%, \quad 75 \%$, and $100 \%$ concentration had effectiveness in inhibiting the growth of Trichophyton rubrum with an average diameter of inhibition formed at each concentration was $10.65 \mathrm{~mm}, 18 \mathrm{~mm}, 26.92 \mathrm{~mm}$ and $37.22 \mathrm{~mm}$ respectively. The antifungal effectiveness was in line with the increasing of cacao bean extract concentration (table 1). These results were consistent with Pelczar and Chan (2008) which stated that the higher concentration of an antifungal material, the antifungal activity also be stronger.

Davis and Stout (1971) categorized the strength of antifungal agents based on the diameter of the inhibitory zone. The diameter of inhibitory zone $\leq 5 \mathrm{~mm}$ is weak, $5-10 \mathrm{~mm}$ is medium, $10-20 \mathrm{~mm}$ is strong, and $\geq 20 \mathrm{~mm}$ is very strong. This study showed that the antifungal activity of cacao bean shells extract on Trichopyhton rubrum growth was in the strong and very strong category.

Kruskal-Wallis test was used to identify a significant difference between groups. KruskalWallis test indicated that there was a significant difference between groups of study $(p=0,003)$. This means that there are differences in the results of inhibitory strength between treatment groups. The differences between groups need to be determined to find out the most effective dose. Mann-Whitney Post Hoc was done, showed significant differences betwen groups.

Table 2. Post hoc Mann-Whitney

\begin{tabular}{ccc}
\hline & Groups & $p$ \\
\hline $25 \%$ & $50 \%$ & 0,021 \\
& $75 \%$ & 0,021 \\
& $100 \%$ & 0,021 \\
& Positive & 0,020 \\
$50 \%$ & Negative & 0,014 \\
& $75 \%$ & 0,021 \\
& $100 \%$ & 0,021 \\
$75 \%$ & Positive & 0,020 \\
& Negative & 0,014 \\
& $100 \%$ & 0,021 \\
$100 \%$ & Positive & 0,020 \\
& Negative & 0,014 \\
Positive & Positive & 0,020 \\
& Negative & 0,014 \\
& Negative & 0,013 \\
\hline
\end{tabular}

Post Hoc Test (Mann-Whitney) among all groups showed a significance value smaller than 0.05 (table 2), which means there were the Trichophyton rubrum growth inhibition. The difference in results obtained in the study be caused by the content of the active substance in each extract concentration tested was different. 
The results of the study showed that cacao bean shells extract concentration had different effectiveness in inhibiting Trichophyton rubrum growth. Between treatment groups there were differences in inhibitory strength, the smallest inhibitory strength was a concentration of $25 \%$, and the strongest was a concentration of $100 \%$, but with a concentration of $50 \%$ cacao bean shells extract has shown strong inhibitory to Trichophyton rubrum growth.

The cacao bean shells extract had not yet been tested for its antifungal effectiveness against other fungi so that the diameter of the inhibitory zone produced in this study could not be compared to similar microorganisms. However, the study of an extract of cacao rind by the dilution method had antifungal effectiveness against Fusarium oxysporum and the phenol content of Liquid Volatile Matter (LVM) at a concentration of $9 \%$ had the potential to be applied as a natural fungicide (Pallawagau et al., 2019). Processed cacao products in the process not only produce bean shells waste, but fruit skin waste. Phytochemical testing of cacao rind extract with $70 \%$ ethanol shows positive alkaloid, saponins, tannins, triterpenoids, flavonoids, and phenols (Rachmawaty et al., 2017). The compound content possessed by cacao bean shells is not much different from the skin of cacao fruit.

Data that has been processed statistically shows that in each variation of the concentration of the treatment group has a significant difference in antifungal activity. This can occur because the extract of cacao bean shells has secondary metabolite compounds that can act as an antifungal. Phytochemical tests showed that cacao bean shells extract is strongly positive contains alkaloids, saponins, and flavonoids which can be used as antifungals (Kayaputri et al., 2014). Flavonoids inhibit the growth of Trichophyton rubrum by down-regulation of genes expressing Fatty Acid Synthase (FAS), an attractive antifungal target because it is a distinguishing element of animal cells and fungal cells (Bitencourt et al., 2014). Role of flavonoids in the pathway of fatty acid synthesis, disrupting the formation of fungal cell walls (Jiang et al., 2016). The group of alkaloid compounds as antifungal works predominantly in membrane cell, it disrupting the structure by breaking the glycan and chitin polymer, causing leakage and cell death. Alkaloid also inhibits the synthesis of DNA, RNA, proteins, and polysaccharides in fungal and another cells (Dheeb, 2015). The underlying mechanism of 
saponins activity are its ability to form complexes with sterols in membrane cells and cause perturbation of membrane (Trdá et al., 2019). Saponin also induces $\mathrm{H}_{2} \mathrm{O}_{2}$, causes peroxidation of fungal lipid membranes and makes cell membrane permeability increased and cell leakage occurs (Jiang et al., 2016).

\section{CONCLUSION}

Cacao bean shells extract (Theobroma cocoa

L.) had in vitro antifungal effectiveness of Trichophyton rubrum growth inhibition by agar well diffusion method, with strong and very strong category result. There were significant differences between all cacao bean shells extract groups $\mathrm{p}<0.05$

\section{REFERENCES}

Bitencourt, T.A., Komoto, T.T., Marins, M., and Fachin, AL. 2014. Antifungal Activity of Flavonoids and Modulation of Expression of Genes of Fatty Acid Synthesis in the Dermatophyte Trichophyton rubrum. BMC proceedings. 8(Suppl 4). p: 53

Dahlan, M.S. and Dewi, J.I. 2009. Statistik untuk Kedokteran dan Kesehatan:Deskriptif, Bivariat dan Multivariate Dilengkapi dengan Menggunakan SPSS. Salemba Medika

Davis, W.W. and Stout, T.R. 1971. Disc Plate Method of Microbiological Antibiotic Assay. Appl Microbiol; 22(4). Pp: 659665
Dheeb, B.I. 2015. Antifungal Activity of Alkaloids and Phenols Compounds Extracted from Black Pepper Piper nigrum Against Some Pathogenic Fungi. Journal of Biotechnology Reasearch Center. 9(2)

Direktorat Jendral Perkebunan (Ditjenbun), 2017. Statistik Perkebunan Indonesia 2016-2018. Direktorat Jenderal Perkebunan. Jakarta

Jiang, X., Feng, K., and Yang, X. 2015. In Vitro Antifungal Activity and Mechanism of Action of Tea Polyphenols and Tea Saponin Against Rhizopus stolonifer. J Mol Microbiol Biotechnol. 25. Pp: 269-76

Kayaputri, I.L., Sumanti, D.M., Indiarto, R., and Dewi, DL. 2014. Kajian Fitokimia Ekstrak Kulit Biji Kakao (Theobroma cocoa L.). Chimica et Natura Acta. 2(1). Pp: 83-90

Kementerian Kesehatan (Kemenkes), Pemerintah RI. 2011. Profil Kesehatan Republik Indonesia Tahun 2010. Jakarta: Kemenkes RI.

Kim, K.H., Lee, K.W., Kim, D.Y., Park, H.H., Kwon, I.B., and Lee, H.J. 2014. Extraction and fractionation of glucosyltransferase inhibitors from cacao bean husk. Process Biochemistry 39. Pp: 2043-46

Pallawagau, M., Yanti, N.A., Jahiding, M., Kadidae, L.O., Asis, W.A., and Hamid, F.H. 2019. Penentuan Kandungan Fenolik Total Liquid Volatile Matter dari Pirolisis Kulit Buah Kakao dan Uji Aktivitas Antfungi terhadap Fusarium oxysporum.ALCHEMY Jurnal Penelitian Kimia.15(1). Pp: 165-179

Pereira, F.D.E., Mendes, J.M., and Lima, D.D.O. 2013. Investigation on Mechanism of Antifungal Activity of Eugenol Against Trichophyton rubrum. Medical Mycology. 51. Pp: 507-513

Pereira, F.D.E, Mendes J.M. Lima, I.O., Mota, K.S.D.L., de Oliveira W.A, and Lima, E.D.O. 2015. Antifungal Activity of Geraniol and Citronellol, Two 
Monoterpenes Alcohols, Against Trichophyton rubrum Involves Inhibiton of Ergosterol Biosynthesis. Pharmaceutical Biology. 53(2). Pp: 228-234

Pires, C.A.A., Lobato, A.M., Carneiro, F.R.O., da Cruz, N.F.S., de Sousa, P.O., and Mendes, A.M.D. 2014. Clinical, Epidemiological, and TPerapeutic Profile of dermatophytosis. An Bas Dermatol. 89(2). Pp: 259-264

Pelczar, M.J. and Chan, E.C.S. 2008. DasarDasar Mikrobiologi Jilid I. Jakarta: UI Press
Rachmawaty, R. Mu'nisa, A., and Hasri, H. 2017. Analisis Fitokimia Ekstrak Kulit Buah Kakao (Theobroma cocoa L.) Sebagai Kandidat Antimikroba. In: Seminar Nasional Lembaga Penelitian "Membangun Indonesia Melalui Hasil Riset", ISBN : 978-602-6883-93-3

Trdá, L., Janda, M., Mackova D., Pospichalova, R., Dobrev, P., Burketova L, and Matusinsky, P. 2019. Dual Mode of The Saponin Aescin in Plant Protection: Antifungal Agent and Plant Defense Elicitor. Frontiers in Plant Scinece.10(1448) 